\title{
Metal- and Affinity-Specific Dual Labeling of Cysteine-Rich Proteins for Identification of Metal-Binding Sites
}

\author{
Manuel David Peris-Díaz, Roman Guran, Ondrej Zitka, Vojtech Adam, and Artur Krężel* \\ Cite This: Anal. Chem. 2020, 92, 12950-12958 \\ Read Online
}

ABSTRACT: Here, using human metallothionein (MT2) as an example, we describe an improved strategy based on differential alkylation coupled to MS, assisted by zinc probe monitoring, for identification of cysteine-rich binding sites with nanomolar and picomolar metal affinity utilizing iodoacetamide (IAM) and $\mathrm{N}$ ethylmaleimide reagents. We concluded that an $\mathrm{S}_{\mathrm{N}} 2$ reaction provided by IAM is more suitable to label free Cys residues, avoiding nonspecific metal dissociation. Afterward, metal-bound Cys can be easily labeled in a nucleophilic addition reaction after separation by reverse-phase $\mathrm{C} 18$ at acidic $\mathrm{pH}$. Finally, we evaluated the efficiency of the method by mapping metal-binding sites of $\mathrm{Zn}_{7-x} \mathrm{MT}$ species using a bottom-up MS approach with respect to

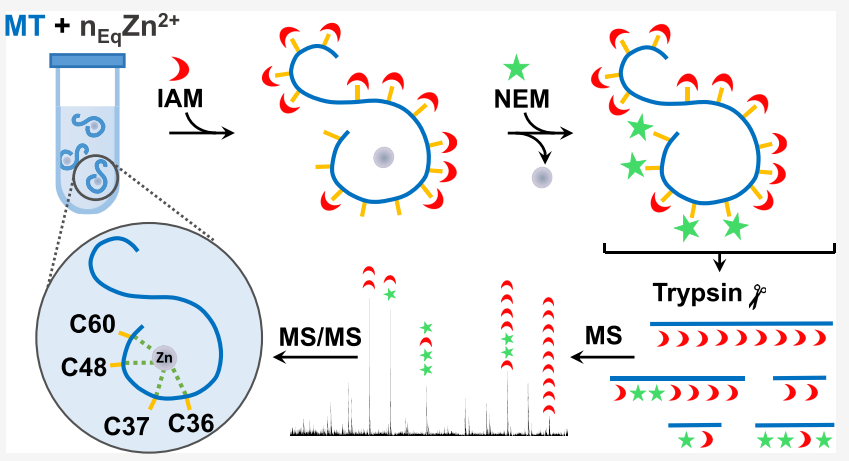
metal-to-protein affinity and element $(\mathrm{al})$ resolution. The methodology presented might be applied not only for MT2 but to identify metal-binding sites in other Cys-containing proteins.

A pproximately one-third of human genes encode proteins 1 that bind metal ions, and in around $10 \%$ of the proteome, $\mathrm{Zn}^{2+}$ ions are used as a catalytic, structural, and regulatory cofactor. $^{1-4}$ Metallothioneins (MTs) play a role in homeostatic control of $\mathrm{Zn}^{2+}$ and $\mathrm{Cu}^{+}$ions in cellular signaling and transduction networks by muffling reactions. ${ }^{5}$ They bind metal ions and serve as both metal donor or acceptor, controlling the cellular $\mathrm{Zn}^{2+}$ fluctuations in the cytosol, nucleus, or mitochondria. ${ }^{6,7}$ Mammalian MTs are low molecular mass $(6-7 \mathrm{kDa})$ cysteine-rich molecules that bind multiple metal ions in a multiple tetrathiolate coordination environment within two separate $M_{x} S_{y}$ clusters. ${ }^{8,9}$ In humans, there exist at least a dozen MT proteins, categorized into subfamilies (MT1-4 isoforms and MT1 subisoforms) depending on sequence, tissue localization, function specificity, or metalbinding properties. ${ }^{8,10}$ Cysteine (Cys) is the most nucleophilic amino acid residue, commonly binding essential as well as toxic metal ions. ${ }^{11,12}$ Moreover, the Cys residue is a cellular target for reactive oxygen, nitrogen, and sulfur species, and it is posttranslationally modified in S-methylation and S-linked acylation, among other reactions. ${ }^{13-16}$ Thus, Cys acts in multiple proteins as a redox switch, depending on the oxidative molecules and metal ion concentration. ${ }^{17-20}$ Because of the aforementioned relevance, a range of experimental and theoretical tools has been developed aimed at identifying different Cys residue states in proteomes. ${ }^{21-24}$ Most of the chemical tools are based on the nucleophilic reaction of Cys toward thiol-specific probes, which may exhibit different reactivity, enabling differentiation of the cysteine sulfur state. $^{25}$ Some of these common protein thiol probes are iodoacetamide (IAM), iodoacetic acid (IAA), N-ethylmaleimide (NEM), methyl methanethiosulfonate (MMTS), Cysreactive mass tag (cys-TMT), and $p$-benzoquinone $(\mathrm{Bq}) .^{21,22}$ Among them, IAM and NEM are commonly used, forming covalent products with sulfhydryl groups by an $S_{N} 2$ nucleophilic substitution or by nucleophilic Michael addition, respectively. ${ }^{13,26}$ NEM reacts with thiols faster than IAM and also exhibits a wider range of $\mathrm{pH}$ applicability. ${ }^{27}$ It shows an appreciable rate even at acidic $\mathrm{pH}$, whereas IAM requires neutral or basic $\mathrm{pH}^{26,27}$ However, NEM exhibits less specificity, which gives rise to side reactions with histidine and lysine residues when NEM is used at large excess or basic $\mathrm{pH} .^{13,26}$ On the other hand, IAM is preferred since it forms a very stable thioether, whereas NEM might undergo partial ring hydrolysis. ${ }^{27}$ These alkylation reagents have been independently used in the past to study $\mathrm{Cd}^{2+}$ binding kinetics, to follow the cluster formation, ${ }^{28-30}$ or to gain insights into partially $\mathrm{Zn}^{2+}$-metalated species in metallothionein. ${ }^{31}$ Other examples include the differential alkylation for mapping Cys redox states, on purified proteins but also in cellular proteomes. ${ }^{32-36}$ Differential alkylation traditionally is based on blocking a reduced free thiol with one alkylator followed by a reduction

Received: April 14, 2020

Accepted: August 3, 2020

Published: August 3, 2020 
step and a second alkylation. ${ }^{25}$ Other derived strategies are based on a dual parallel experiment in which a native protein and the treated protein are both labeled by the alkylation reagent. ${ }^{31,37}$ For instance, if one is interested in localizing metal-binding Cys residues, the protein is treated by removing the metal ion by chelation or reducing the $\mathrm{pH}$ to promote metal dissociation and then labeling. ${ }^{37-39}$ Subsequently, by comparing both experiments, the native metalloprotein labeled and the treated protein, one might inquire into a particular Cys residue participating in metal ion binding. ${ }^{31}$ This methodology coupled to state-of-art mass spectrometry (MS) techniques has been successfully used in the past in $\mathrm{Cd}^{2+}$ - and $\mathrm{Zn}^{2+}$-containing MT studies. ${ }^{31,37,40,41}$ Despite the efforts and advances made, these methods still present several limitations in metalloproteomic studies. ${ }^{42}$ In principle, a metal-bound thiolate would decrease its reactivity toward nucleophiles and thus no modification would occur under controlled conditions because it is metal-protected. ${ }^{24,40,43}$ This is a fact for a kinetically inert metal-Cys bond. ${ }^{44}$ For instance, 2 out of 10 Cys residues from the p53 core domain were found to be reactive toward NEM. ${ }^{45}$ Identification of the Cys positions revealed that they do not belong to the $\mathrm{Zn}(\mathrm{Cys})_{3}$ (His) core, which remained unmodified. ${ }^{45}$ Not only the kinetic stability but also the thermodynamic stability of the metal-protein complex dictates how the reaction proceeds. In the presence of the same ligand, properties of the metal ion influence the thermodynamic stability of the protein complex. For instance, $\mathrm{Cd}^{2+}$, which in terms of the hard-soft acid-base concept is significantly softer than $\mathrm{Zn}^{2+}$, is bound more strongly to $\mathrm{Cys}_{4}$ sites and more weakly to the $\mathrm{Cys}_{2} \mathrm{His}_{2}$ core. ${ }^{46}$ Therefore, proteins with a low or moderate $\mathrm{Zn}^{2+}$ binding affinity $\left(\log K_{\mathrm{b}}\right.$ of $\left.7-10\right)$ and kinetically labile metal-protein bonds, such as MT2, might reveal other scenarios. ${ }^{47}$ The alkylator concentration and time of reaction should be particularly optimized to avoid $\mathrm{Zn}^{2+}$ dissociation from the reactive $\mathrm{Zn}^{2+}$-bound Cys residue. Unlike traditional differential alkylation, a similar reactivity might appear for a metal-bound Cys and for a free Cys residue with a low $\mathrm{p} K_{a}$, which hinders their nucleophilic differentiation. ${ }^{23-25}$ The local electrostatic environment will affect the acidity of Cys residues present in the protein, dictating the reactivity toward the electrophile. ${ }^{48}$ This might lead to situations in which an $\mathrm{M}(\mathrm{Cys})_{4}$ core is alkylated without metal dissociation. The situation where a reactive Cys residue participates in coordination of both a metal ion and an alkylator moiety has been previously observed. ${ }^{28,37,49}$ Three possible scenarios need to be contemplated: (i) alkylation of a free Cys residue, (ii) alkylation of a metal-bound Cys residue without metal ion dissociation, and (iii) alkylation of a metal-bound Cys residue and subsequent metal ion dissociation. Therefore, finding a reagent or reaction conditions that distinguish between free Cys and metal-protected Cys residues is a fundamental issue. Moreover, high-resolution methods such MS are greatly needed to follow the modification extent but also to identify metal-binding sites. ${ }^{50,51}$ Using soft electrospray ionization (ESI) conditions and transmission parameters, native conditions might be preserved during ESI-MS analysis, maintaining the noncovalent metal-protein interactions, the solutionphase populations, and the conformational states for the labeled metal-bound protein. ${ }^{52-56}$ During the last 2 decades, a vast number of research studies have applied ESI-MS for MT investigations. $^{28,31,37,40,57-59}$ To map the modification sites, top-down sequencing provides an easy and fast way, although it still provides a lower sequencing coverage than bottom-up approaches. ${ }^{60,61}$

Here, we describe an improved strategy based on differential alkylation coupled to MS for identification of multi-Cys metalbinding sites with nanomolar and picomolar metal affinity in MT2 by utilizing IAM and NEM reagents. First, we studied the kinetic and thermodynamic lability of $\mathrm{Zn}^{2+}-$ and $\mathrm{Cd}^{2+}-$ thiolate bonds in $\mathrm{Zn}_{7} \mathrm{MT} 2$ and $\mathrm{Cd}_{7} \mathrm{MT} 2$ using both alkylators and analyzed them by UV-vis, matrix-assisted-laser desorption ionization mass spectrometry (MALDI-MS), and ESI-MS methods. Most biophysical research has used $\mathrm{Cd}^{2+}$ for MT study since it produces well-defined spectroscopic signals, in contrast to spectroscopically silent $\mathrm{Zn}^{2+}{ }^{31}$ Notably, MTs were originally isolated as a mixed $\mathrm{Zn}^{2+} / \mathrm{Cd}^{2+}$ complex. ${ }^{8}$ For our purposes, MT2 was used as a model of a protein with various low, moderate, and high $\mathrm{Zn}^{2+}$ binding affinities. It is worth noting that the first three $\mathrm{Zn}^{2+}$ ions dissociating from MT2 demonstrate nano- and subnanomolar affinity, perfect for this investigation. Comparing the reactivity with the more thermodynamically stable $\mathrm{Cd}_{7} \mathrm{MT} 2$ protein (low pico- and femtomolar affinity) illustrated the issue regarding the metalprotein stability and the phenomena of metal dissociation. Through this, we ranked and ordered the reactivity, allowing us to develop a differential alkylation strategy to map partially $\mathrm{Zn}^{2+}$-loaded $\mathrm{Zn}_{7-x} \mathrm{MT} 2$ species. We demonstrated that IAM is more suitable than NEM to be used as the first labeling reagent in order to label free Cys residues. The lower reactivity of IAM prevents the metal ion dissociation, whereas its small size and hydrophilic character allow access to buried free thiols. ${ }^{40,62}$ This step was followed by metal ion removal with acidification and a subsequent second labeling reaction with NEM. Although we and others demonstrated that addition of NEM without acidification may dissociate all seven $\mathrm{Zn}^{2+}$ from $\mathrm{Zn}_{7} \mathrm{MT} 2$, different conclusions are found for $\mathrm{Cd}_{7} \mathrm{MT} 2$. $^{28,30}$ NEM did not dissociate all seven $\mathrm{Cd}^{2+}$ due to the higher $\mathrm{Cd}^{2+}$ to-protein affinity. Another factor that may limit the metal ion dissociation with addition of NEM without acidification is the thiol accessibility. The low $\mathrm{pH}$ greatly facilitates the access of NEM to all of the Cys residues, independently if they were buried or solvent-exposed Cys residues. ${ }^{24}$ For this purpose, NEM offers faster kinetics than iodoacetamide derivatives, even at low $\mathrm{pH}^{26,27}$ Thus, in order to elaborate a general method that may be applicable for other Cys-containing proteins, with higher metal-to-protein affinity and with different thiol accessibility, ${ }^{63,64}$ we introduced an acidification step prior to NEM labeling. Altogether, this ensures metal ion removal independent of how strongly they are bound and facilitates the access of NEM to the thiols. Afterward, utilizing the differential alkylation developed, we identified the $\mathrm{Zn}^{2+}$ binding Cys residues in $\mathrm{Zn}_{7-x} \mathrm{MT} 2$ species with a bottom-up MS approach. The methodology presented herein represents a general technique to study metal-binding Cys-containing proteins, independently of their metal-binding properties and protein structure.

\section{EXPERIMENTAL SECTION}

Materials. All reagents used were purchased from SigmaAldrich (Merck Group), Acros Organic, Roth, BioShop, VWR International (Avantor), and Iris-Biotech $\mathrm{GmbH}$. The $\mathrm{pH}$ buffers and solutions were prepared with Milli-Q water (Merck Millipore), incubated with Chelex 100 resin (Bio-Rad) and degassed to eliminate trace metal ion contamination. For more 
A
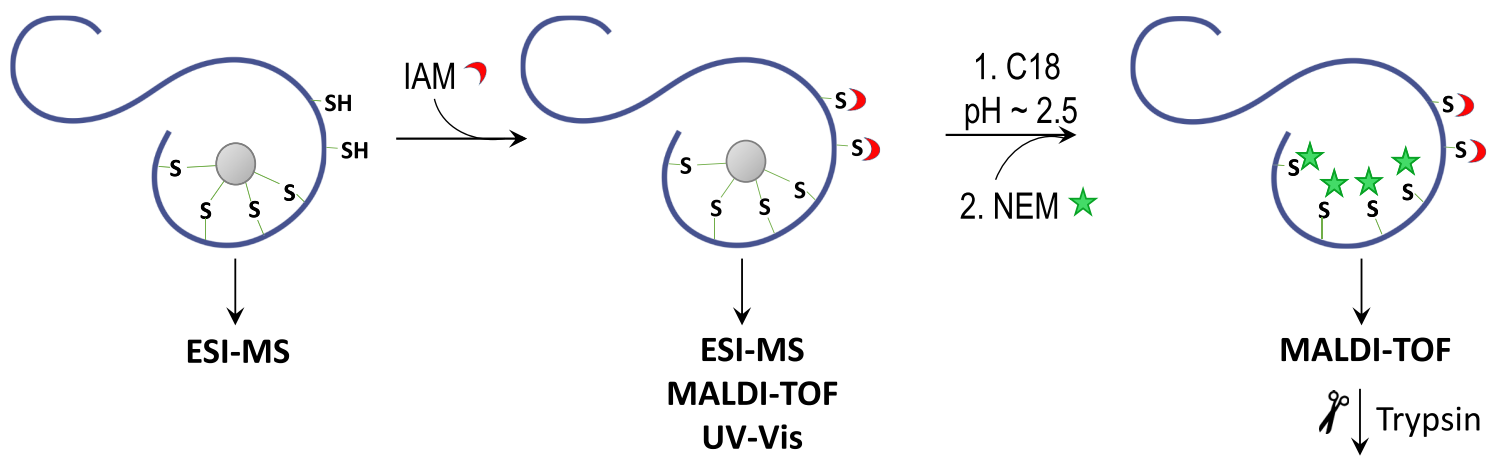

MALDI-TOF/TOF

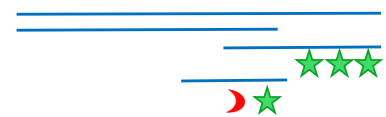

B

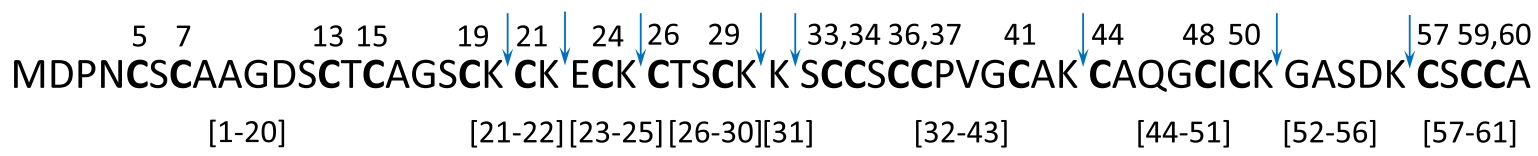

Figure 1. Overview of the hereby presented differential labeling approach. (A) Steps of the procedure for labeling free- and metal-bound Cys residues by IAM and NEM, respectively. (B) Human metallothionein-2 (MT2) sequence with indicated tryptic fragments and position numbers of Cys residues. Arrows indicate the cleavage positions of the C-terminal lysine, specific for trypsin enzyme.

detailed information about materials employed see the Supporting Information (SI).

Expression and Purification of Metallothionein. MT2 (Addgene plasmid ID 105693) was overexpressed in a bacterial system and purified as previously described. ${ }^{31}$ Detailed information may be found in the SI.

Reactions of $\mathrm{Zn}_{7} \mathrm{MT}$ and $\mathrm{Cd}_{7} \mathrm{MT}$ with NEM and IAM Alkylation Reagents. To study the metal release reactions, $15 \mu \mathrm{M} \mathrm{Zn} \mathrm{Z}_{7} \mathrm{MT} 2$ or $\mathrm{Cd}_{7} \mathrm{MT} 2$ in $50 \mathrm{mM}$ ammonium acetate (pH 7.4) and $1 \mathrm{mM}$ tris(2-carboxyethyl)phosphine (TCEP) solution were incubated with a total of $0.01,15,40,180,715$, 1400 , and $3600 \mathrm{~mol}$ equiv of IAM or NEM for 15 and $60 \mathrm{~min}$ at $25{ }^{\circ} \mathrm{C}$ in darkness. All solutions and plastic tubes were previously degassed by purging with nitrogen. To measure the modification profile by MALDI-MS, an aliquot of $12 \mu \mathrm{L}$ was taken for each sample and purified by ZipTip $\mu$-C18 with $5 \mu \mathrm{L}$ of Milli-Q water/acetonitrile (ACN) solution (50:50, v/v) for elution. The rest of the sample $(80 \mu \mathrm{L})$ was purified using a 3 $\mathrm{kDa}$ Amicon Ultra-4 Centrifugal Filter for $10 \mathrm{~min}$ under a nitrogen blanket and analyzed by ESI-MS. Care was taken to avoid oxidation of the free thiols, ${ }^{37}$ using a low capillary voltage $(2 \mathrm{kV})$, in the presence of $1 \mathrm{mM}$ TCEP and a nitrogen blanket. We used TCEP as a reducing agent since it binds zinc less tightly than DL-dithiothreitol (DTT) (submillimolar affinity). ${ }^{31}$ Under our experimental conditions, we did not observe oxidation of thiols, as confirmed by ESI-MS analysis.

Identification of $\mathrm{Zn}^{2+}$-Binding Sites by a Dual Labeling Strategy. $\mathrm{Zn}_{7} \mathrm{MT} 2$ was purified by size exclusion chromatography with $10 \mathrm{mM} \mathrm{HCl}$, and the concentration of apoMT was estimated by 5,5'-dithiobis(2-nitrobenzoic acid) and $\mathrm{Cd}^{2+}$ titration experiments. Then, apoMT was saturated with 4, 5, 6, or 7 mol equiv of $\mathrm{ZnSO}_{4}$ under a nitrogen blanket in the presence of $1 \mathrm{mM}$ TCEP, followed by buffer exchange to $50 \mathrm{mM}$ ammonium acetate $(\mathrm{pH} 7.4)$ and purification with a 10 min spin time (three times) using $3 \mathrm{kDa}$ Amicon filters, purging nitrogen, and addition of $1 \mathrm{mM}$ TCEP at each round.
Partially metalated proteins were subsequently analyzed by ESI-MS. Then, a $15 \mu \mathrm{M} \mathrm{Zn}_{0-7} \mathrm{MT} 2$ aliquot was incubated in 1 mM IAM ( $\left.15 \mathrm{~min}, 25^{\circ} \mathrm{C}\right)$ in darkness. From this, an aliquot was purified by ZipTip $\mu$-C18, as done previously, and measured by MALDI-MS. Another aliquot was analyzed by ESI-MS. The rest of the sample $(80 \mu \mathrm{L})$ followed the duallabeling strategy. First, the $\mathrm{pH}$ was reduced with $0.1 \%$ formic acid (FA) and $1 \mathrm{mM}$ DTT and the excess IAM removed by purification with $\mathrm{C} 18$ resin. Eluted protein was double-labeled with incubation in $3 \mathrm{mM}$ NEM $\left(30 \mathrm{~min}, 25^{\circ} \mathrm{C}\right)$. After that, an aliquot was analyzed by MALDI-MS. The rest of the sample underwent a bottom-up MS approach by digestion in a solution using trypsin at a weight ratio of $1: 20$ (30 min, 37 ${ }^{\circ} \mathrm{C}$ ). The trypsinization reaction was quenched by addition of $5 \mu \mathrm{L}$ of $0.1 \%$ FA.

UV-Vis Spectroscopy. UV-vis spectra were recorded on a JASCO V-650 spectrophotometer at $25{ }^{\circ} \mathrm{C}$ with a $1 \mathrm{~cm}$ quartz cuvette. The $\mathrm{Zn}_{7} \mathrm{MT} 2$ and $\mathrm{Cd}_{7} \mathrm{MT} 2$ reactions with NEM and IAM were followed at $492 \mathrm{~nm}$ using $100 \mu \mathrm{M}$ Zincon (ZI) or 4-(2-pyridylazo)resorcinol (PAR) in $20 \mathrm{mM}$ Tris- $\mathrm{HCl}$ ( $\mathrm{pH} 7.4, \mathrm{NaCl} 150 \mathrm{mM}$ ) buffer, respectively. ${ }^{65,66}$ To avoid oxidation, $1 \mathrm{mM}$ TCEP was used as a non-metal-binding reducing agent. The reactions were followed at 618 and 492 $\mathrm{nm}$, respectively, for a period of $0-24 \mathrm{~h}$.

ESI-MS. ESI-MS experiments were performed on a quadrupole time-of-flight (qTOF) Bruker Maxis Impact mass spectrometer (Bruker Daltonik GmbH, Bremen, Germany) calibrated with a commercial ESI-TOF tuning mix (SigmaAldrich). Samples were directly infused with a $1 \mu \mathrm{L} / \mathrm{min}$ flow rate. ESI-MS spectra were recorded in positive mode with a capillary voltage of $2 \mathrm{kV}$, end plate offset potential of $500 \mathrm{~V}$, nebulizer gas $\left(\mathrm{N}_{2}\right)$ pressure of 1.5 bar, drying gas $\left(\mathrm{N}_{2}\right)$ flow rate of $4 \mathrm{~L} / \mathrm{min}$, and drying temperature of $180{ }^{\circ} \mathrm{C}$. The mass range was set from 500 to $3000 \mathrm{~m} / z$ and recorded and averaged over $1 \mathrm{~min}$. The Bruker Compass data analysis 
Table 1. Oxidative Alkylation and Subsequent Metal Dissociation from $\mathrm{Zn}_{7} \mathrm{MT} 2$ and Cd 7 MT2 Followed with MALDI-MS, ESIMS, and UV-Vis Experiments at Increasing Concentrations of IAM and NEM Alkylating Reagents

\begin{tabular}{|c|c|c|c|c|c|c|c|}
\hline \multirow[b]{2}{*}{ equiv } & \multirow[b]{2}{*}{ protein } & \multicolumn{3}{|c|}{ NEM } & \multicolumn{3}{|c|}{ IAM } \\
\hline & & $\begin{array}{l}\text { species } \\
\text { (ESI-MS) }\end{array}$ & $\begin{array}{l}\text { metal ions transferred } \\
\text { (UV-vis) }\end{array}$ & $\begin{array}{l}\text { Cys residues modified } \\
\text { (MALDI-MS) }\end{array}$ & $\begin{array}{l}\text { species } \\
(\text { ESI-MS) }\end{array}$ & $\begin{array}{l}\text { metal ions transferred } \\
\text { (UV-vis) }\end{array}$ & $\begin{array}{l}\text { Cys residues modified } \\
\text { (MALDI-MS) }\end{array}$ \\
\hline 15 & $\mathrm{Cd}_{7} \mathrm{MT}$ & $\mathrm{Cd}_{7} \mathrm{NEM}_{0-1}$ & 0.4 & 0.5 & $\mathrm{Cd}_{7} \mathrm{IAM}_{0-1}$ & 0.0 & 0.5 \\
\hline & $\mathrm{Zn}_{7} \mathrm{MT}$ & $\mathrm{Zn}_{7} \mathrm{NEM}_{0-1}$ & 2.5 & 1.0 & $\mathrm{Zn}_{7} \mathrm{IAM}_{0-1}$ & 0.0 & 0.6 \\
\hline 40 & $\mathrm{Cd}_{7} \mathrm{MT}$ & $\begin{array}{l}\mathrm{Cd}_{6} \mathrm{NEM}_{2-3} \\
\mathrm{Cd}_{7} \mathrm{NEM}_{2-3}\end{array}$ & 1.2 & 2.5 & $\mathrm{Cd}_{7} \mathrm{IAM}_{0-1}$ & 0.0 & 0.5 \\
\hline & $\mathrm{Zn}_{7} \mathrm{MT}$ & $\mathrm{Zn}_{\mathbf{4}} \mathrm{NEM}_{9-11}^{b}$ & 3.0 & 10.0 & $\mathrm{Zn}_{7} \mathrm{IAM}_{0-1}$ & 0.5 & 1.0 \\
\hline 180 & $\mathrm{Cd}_{7} \mathrm{MT}$ & $\mathrm{Cd}_{4} \mathrm{NEM}_{9-11}$ & 1.3 & 7.5 & $\mathrm{Cd}_{6} \mathrm{IAM}_{3-5}$ & 0.3 & 2.5 \\
\hline & $\mathrm{Zn}_{7} \mathrm{MT}$ & $\mathrm{Zn}_{0} \mathrm{NEM}_{19-20}$ & 5.6 & 17.5 & $\mathrm{Zn}_{4} \mathrm{IAM}_{9-11}$ & 1.0 & 6.0 \\
\hline 750 & $\mathrm{Cd}_{7} \mathrm{MT}$ & $\mathrm{Cd}_{4} \mathrm{NEM}_{10-12}$ & 2.3 & 11.0 & $\mathrm{Cd}_{4} \mathrm{IAM}_{9-10}$ & 0.3 & 7.0 \\
\hline & $\mathrm{Zn}_{7} \mathrm{MT}$ & $\mathrm{Zn}_{0} \mathrm{NEM}_{19-20}$ & 6.7 & 19.0 & $\begin{array}{l}\mathrm{Zn}_{\mathbf{0}} \mathrm{IAM}_{\mathbf{1 9 - 2 0}} \\
\mathrm{Zn}_{1} \mathrm{IAM}_{15-1} \\
\mathrm{Zn}_{2} \mathrm{IAM}_{6-12}\end{array}$ & 2.4 & 14.0 \\
\hline 1400 & $\mathrm{Cd}_{7} \mathrm{MT}$ & $\mathrm{Cd}_{4} \mathrm{NEM}_{9-11}$ & 2.7 & 12.5 & $\begin{array}{l}\mathrm{Cd}_{\mathbf{0}} \mathrm{IAM}_{\mathbf{1 8 - 2 0}} \\
\mathrm{Cd}_{2} \mathrm{IAM}_{17} \\
\mathrm{Cd}_{3} \mathrm{IAM}_{14}\end{array}$ & 1.2 & 13.0 \\
\hline & $\mathrm{Zn}_{7} \mathrm{MT}$ & $\mathrm{Zn}_{0} \mathrm{NEM}_{19-20}$ & 6.8 & 19.5 & $\begin{array}{l}\mathrm{Zn}_{0} \mathrm{IAM}_{18-20} \\
\mathrm{Zn}_{1} \mathrm{IAM}_{15-16} \\
\mathrm{Zn}_{2} \mathrm{IAM}_{6-12}\end{array}$ & 3.5 & 14.5 \\
\hline
\end{tabular}

${ }^{a}$ Refers to the average number of Cys residues modified. ${ }^{b}$ The bolded text represents the main species presented in Scheme 1.

software package and in-house $\mathrm{R}$ scripts were used to analyze the data.

MALDI-MS. A MALDI-TOF/TOF MS Bruker UltrafleXtreme instrument (Bruker Daltonik GmbH, Bremen, Germany) was used for MALDI-MS experiments. 2,5Dihydroxybenzoic acid (DHB) and $\alpha$-cyano-4-hydroxycinnamic acid (HCCA) were used as the MALDI-TOF matrix for protein and peptide analysis, respectively. The saturated matrix solution was prepared in $30 \% \mathrm{ACN}$ and $0.1 \%$ trifluoroacetic acid. MALDI-MS analysis of proteins was performed in a linear positive mode in the $2-20 \mathrm{kDa}$ range. The mass spectra were typically acquired by averaging 2000 subspectra from a total of 2000 laser shots per spot. The laser power was set at 5-10\% above the threshold. The calibration was done using a standard peptide and protein calibration mixture obtained from Bruker (Bruker Daltonik GmbH, Bremen, Germany). MALDI-TOF/ TOF measurements of peptides were performed in reflector positive mode in the $0-4 \mathrm{kDa}$ range. Moreover, a LIFT cell was used for MS/MS analysis of detected peptides. ${ }^{67}$ The instrument was controlled by flexControl ver. 3.4 and flexAnalysis ver. 3.4 software. BioTools 3.2 SR3 and Sequence Editor (Bruker Daltonik GmbH, Bremen, Germany) were used to analyze the MALDI-MS data.

\section{RESULTS AND DISCUSSION}

The first part of this research attempted to study the kinetic and thermodynamic lability of $\mathrm{Zn}^{2+}$-thiolate bonds in fully saturated $\mathrm{Zn}_{7} \mathrm{MT} 2$ and to compare it with its cadmium counterpart. To do so, zinc and cadmium proteins were incubated with increasing concentrations of both alkylation reagents NEM and IAM for different periods of time. The reaction was then simultaneously followed by native ESI-MS and MALDI-MS (Figure 1A). Complementarily, UV-vis spectrophotometric studies were carried out using chromophoric chelating probes $\mathrm{ZI}$ and PAR, respectively, to monitor the $\mathrm{Zn}^{2+}$ and $\mathrm{Cd}^{2+}$ dissociation upon protein modification. $\mathrm{ZI}$ forms a weak ZnZI complex with a dissociation constant of $K_{\mathrm{d}}$ $=2.09 \times 10^{-6} \mathrm{M}$ at $\mathrm{pH} 7.4^{65}$ that ensures no $\mathrm{Zn}^{2+}$ competition with $\mathrm{Zn}_{7} \mathrm{MT} 2$ protein. Because $\mathrm{Cd}^{2+}$ binds less tightly to $\mathrm{ZI}$ than $\mathrm{Zn}^{2+}$, we could apply PAR to monitor the $\mathrm{Cd}^{2+}$ dissociation upon alkylation in a more quantitative way without $\mathrm{Cd}^{2+}$ competition with $\mathrm{Cd}_{7} \mathrm{MT} 2 .{ }^{65,66}$ No doubt, ESI can retain the native-like structures, possibly because of the kinetic trapping effect. ${ }^{68}$ However, complementing gas-phase MS and solution experiments might require caution to be taken due to concentration-dependent rate limitations, differences in the solvent composition, or $\mathrm{pH}$-induced changes. ${ }^{69}$ However, general trends and conclusions obtained from both gas-phase and solution experiments matched very well, as will be presented in the next section.

Profiling Reactive Cysteine Residues in $\mathrm{Zn}_{7} \mathrm{MT} 2$ and $\mathrm{Cd}_{7}$ MT2 Proteins by NEM and IAM. The oxidative alkylation and subsequent metal dissociation from $\mathrm{Zn}_{7} \mathrm{MT} 2$ and $\mathrm{Cd}_{7} \mathrm{MT} 2$ were followed with MALDI-MS, ESI-MS, and $\mathrm{UV}-$ vis experiments at increasing concentrations of both alkylating reagents and as a function of time (Table 1 and Figures 2 and 3). Note that in solution experiments detected ca. 1 equiv less of $\mathrm{Cd}^{2+} / \mathrm{Zn}^{2+}$ displaced than for the gas-phase experiments for the same reaction time $(60 \mathrm{~min})$ (Figure S3, SI). The detected number of metal ions displaced at $200 \mathrm{~min}$ using UV-vis experiments followed a similar pattern as obtained at $60 \mathrm{~min}$ in the gas-phase experiments. However, particular differences encountered may be attributed to $\mathrm{pH}$ induced changes, as ammonium acetate likely undergoes acidification in the ESI plume, ${ }^{69}$ or to differences due to the absence of nonvolatile salts in ESI-MS. ${ }^{70}$ As demonstrated with submicron electrospray emitters, the concentration of $\mathrm{NaCl}$ might stabilize protein conformations toward more compact structures. $^{70,71}$ Besides, the spectroscopic signal is an average response of all the species in solution. Figure 2 contains the Cys modification profile obtained with MALDI-MS and the number of metal ions transferred to PAR and ZI measured with UV-vis, as a function of NEM or IAM concentration. The data shows that small amounts of both NEM or IAM lead to a single cysteine alkylated without metal dissociation [Table 1 and Figure S4 (SI)]. Noticeable differences in the reaction of 

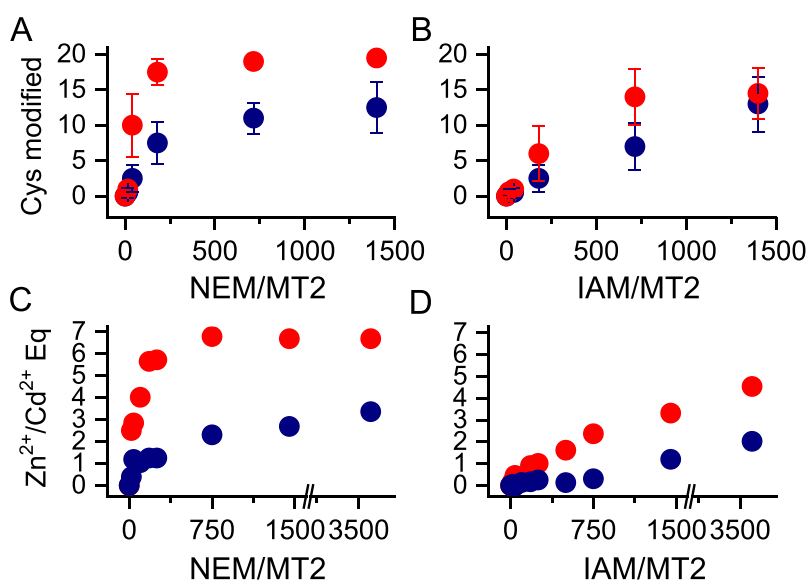

Figure 2. Dependence of the molar ratio (0-3600 equiv) of alkylating agents NEM and IAM on the Cys residue modification (A and B, respectively) monitored with MALDI-MS and the metal dissociation from $\mathrm{Zn}_{7} \mathrm{MT} 2$ and $\mathrm{Cd}_{7} \mathrm{MT} 2$ analyzed by $\mathrm{UV}$-vis spectrophotometry (C and D, respectively). MALDI-MS and UV-vis spectra were recorded after 60 and $200 \mathrm{~min}$ of sample incubation at $25{ }^{\circ} \mathrm{C}$. Metal ion dissociation was analyzed using Zincon and PAR assays. ${ }^{59,60}$ Red and blue stand for $\mathrm{Zn}_{7} \mathrm{MT} 2$ and $\mathrm{Cd}_{7} \mathrm{MT} 2$, respectively. $\mathrm{Cd}^{2+}$ and $\mathrm{Zn}^{2+}$ refer to $\mathrm{Zn}_{7} \mathrm{MT} 2$ and $\mathrm{Cd}_{7} \mathrm{MT} 2$ proteins.

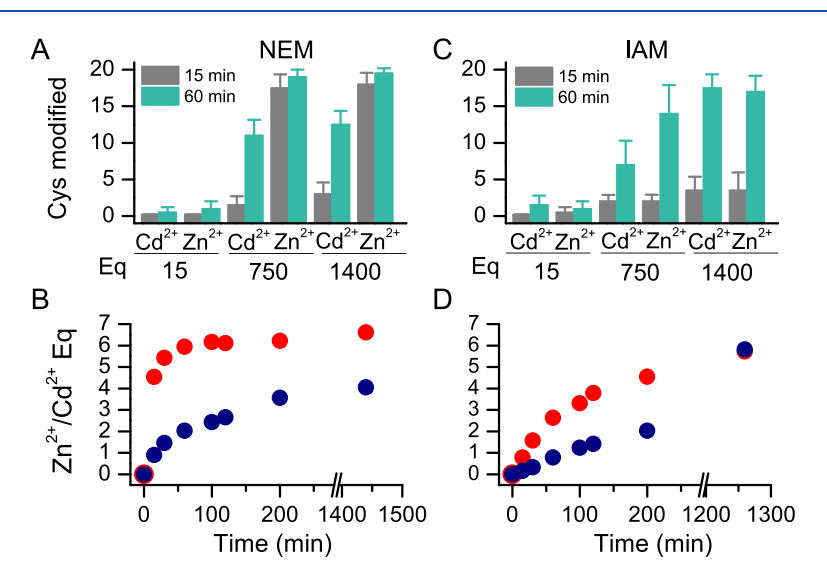

Figure 3. Analysis with bar plot of MALDI-MS cysteine profiling for $\mathrm{Cd}_{7} \mathrm{MT} 2$ and $\mathrm{Zn}_{7} \mathrm{MT} 2$ to which 15,750 , and 1400 equiv of NEM or IAM (A and C, respectively) had been added and incubated with for 15 and $60 \mathrm{~min}$ at $25{ }^{\circ} \mathrm{C}$. UV-vis experiments of $\mathrm{Cd}_{7} \mathrm{MT} 2$ and $\mathrm{Zn}_{7}$ MT2 to which 3600 equiv of NEM had been added and incubated with for 0-1450 min (B and D, respectively). Red and blue stand for $\mathrm{Zn}_{7} \mathrm{MT} 2$ and $\mathrm{Cd}_{7} \mathrm{MT} 2$, respectively. Gray and cyan stand for 15 and $60 \mathrm{~min}$ of alkylation, respectively.

NEM with $\mathrm{Zn}_{7} \mathrm{MT} 2$ were observed in the gas phase and in solution (Table 1). Meanwhile, ESI-MS captured the intermediate $\mathrm{Zn}_{7} \mathrm{NEM}_{1} \mathrm{MT} 2$, and approximately $2.5 \mathrm{Zn}^{2+}$ dissociated rapidly in solution [Table 1 and Figure S4 (SI)]. The number of $\mathrm{Zn}^{2+}$ detected by UV-vis practically did not change after addition of 40 equiv of alkylator, but the product ion $\left[\mathrm{Zn}_{4} \mathrm{NEM}_{9-11} \mathrm{MT} 2\right]^{5+}$ showed up in the ESI-MS spectra [Figure 2A, Table 1, and Figure S4 (SI)]. These results are consistent with the 10 Cys being NEM-labeled, suggesting a concomitant full $\beta$-domain modification, where $3 \mathrm{Zn}^{2+}$ had been dissociated (Figure 2A). The reaction intermediate $\mathrm{Zn}_{4} \mathrm{NEM}_{9-11} \mathrm{MT} 2$ disappeared after addition of 180 equiv of NEM with the formation of metal-depleted MT $\left(\mathrm{NEM}_{20} \mathrm{MT} 2\right)$ [Table 1 and Figure S4 (SI)]. Its $\mathrm{Cd}^{2+}$ counterpart $\left(\mathrm{Cd}_{4} \mathrm{NEM}_{9-11} \mathrm{MT} 2\right)$ appeared and remained the most abundant, even at large molar excess, which clearly shows the higher $\mathrm{Cd}^{2+}$-to-protein affinity. On the other hand, less reactive IAM required at least 180 equiv to provoke $\mathrm{Zn}^{2+}$ dissociation and to form the intermediates $\mathrm{Zn}_{4} \mathrm{IAM}_{9-11} \mathrm{MT} 2$. In disagreement, UV-vis experiments showed that only one $\mathrm{Zn}^{2+}$ dissociated from the protein. Note that the spectroscopic signal obtained is the average response from dynamic equilibria between multiple species. This hypothesis is supported by the Cys modification profile that showed a broad number of modifications (Figure 2B). Increasing to 750 equiv of alkylator leads to the formation of the intermediate $\mathrm{Cd}_{4} \mathrm{LAM}_{9-10} \mathrm{MT} 2$ and the species $\mathrm{Zn}_{0-2} \mathrm{IAM}_{0-12} \mathrm{MT} 2$ that were metal-stripped after doubling the IAM concentration [Table 1, Figure 2B, and Figure S5 (SI)]. Interestingly, IAM was able to alkylate and dissociate the four $\mathrm{Cd}^{2+}$ from the $\mathrm{Cd}_{4}(\mathrm{Cys})_{11} \alpha$-domain, while the intermediate $\mathrm{Cd}_{4} \mathrm{NEM}_{9-11} \mathrm{MT} 2$ remained stable. Thus, not only the higher metal-to-protein affinity but also the bigger size of NEM inhibits the access to the thiols buried in the $\mathrm{Cd}_{4} S_{11}$ cluster. In agreement with ESI-MS experiments, NEM reached a plateau with ca. $11 \mathrm{Cys}$ modified for $\mathrm{Cd}_{7} \mathrm{MT} 2$ (Figures $2 \mathrm{~A}$ and $3 \mathrm{~A}$ ). UV-vis confirmed that, even after $24 \mathrm{~h}$ of incubation with 3600 equiv of NEM, no more than 4 equiv of $\mathrm{Cd}^{2+}$ was detected (Figure 3B). IAM, on the other hand, did not stabilize any intermediate (Figure $3 \mathrm{C}, \mathrm{D}$ ).

In the light of these results, we interpret the data as follows (Scheme 1): NEM empties out the $\beta$-domain faster than IAM, forming the $\mathrm{Cd}_{4} \mathrm{MT} 2 \alpha$-cluster or a $\mathrm{Zn}_{4} \mathrm{MT} 2$ where the $\mathrm{Zn}^{2+}$ are redistributed within the $\alpha$ - and $\beta$-domains. The higher $\mathrm{Cd}^{2+}-\mathrm{S}$ bond stability was directly probed for both alkylator reagents. Similarly, the latter occurs for the $\alpha, \beta-\mathrm{Zn}_{4} \mathrm{MT}$

Scheme 1. Summary of the Structures Obtained as the Reaction Progressed Followed by either Increasing the Equivalents of NEM or IAM or Increasing the Reaction Time $^{a}$

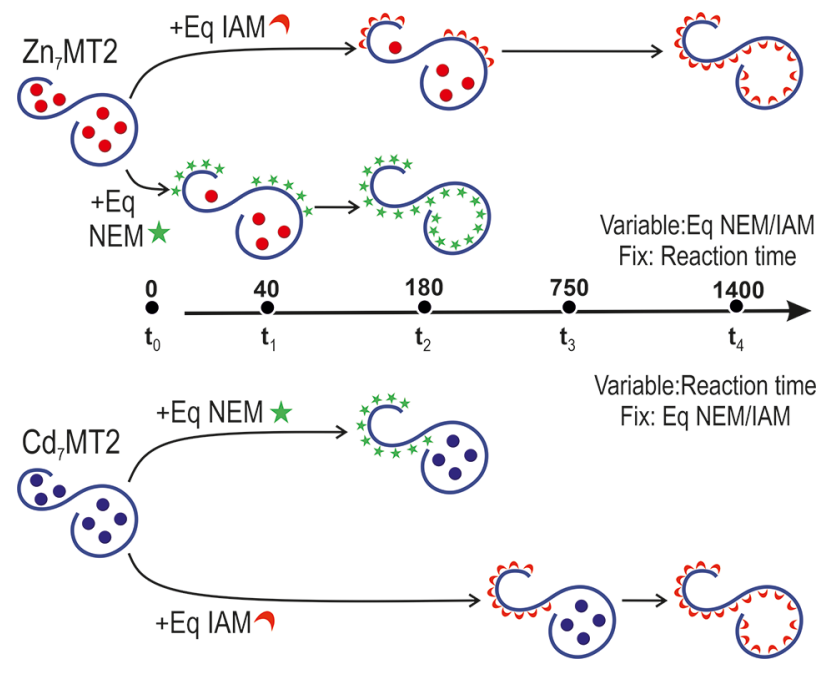

${ }^{a}$ The structures are based on the combination of the methods explored in this research, through cysteine profiling with MALDI-MS and metal probe monitoring with UV-vis and native ESI-MS. The $\mathrm{Zn}_{7} \mathrm{MT} 2$ and $\mathrm{Cd}_{7} \mathrm{MT} 2$ proteins were incubated with NEM or IAM at different molar equivalents (e.g. 40, 180, 750, and 1400) for $60 \mathrm{~min}$. In the other option, the proteins were incubated at fixed molar equivalents of NEM or IAM ( 3600 equiv for UV-vis and 750 or 1400 equiv for MALDI-MS and ESI-MS), and the reaction was followed over time (0-1450 min for UV-vis and 0-60 min for MALDI-MS and ESI-MS). 
product, indicating lower kinetic lability (indeed, more inert to breaking metal-ligand bonds). Subsequently, IAM dissociated the four $\alpha$-domain $\mathrm{Cd}^{2+}$ and NEM still did not dissociate the remaining $\alpha-\mathrm{Cd}_{4} \mathrm{~S}_{11}$ cluster. This suggests an additional factor to $\mathrm{Cd}^{2+}-\mathrm{S}$ bond stability preventing the disruption of $\mathrm{Cd}_{4} \mathrm{NEM}_{9-11} \mathrm{MT} 2$. Therefore, the lower IAM reactivity could benefit the mapping of free Cys residues without altering metal-binding sites, even in these proteins with low metal-toprotein affinity. The small size and hydrophilic character of IAM allows Cys-labeling, even for the Cys residues that are buried. $^{40,62}$

Mapping the $\mathbf{Z n}_{4-7} \mathrm{MT} 2$ Species-Pinpointing the $\mathrm{Zn}^{2+}$-Binding Sites. The previous results helped us with the main aim of this research: the improvement of a differential alkylation strategy to map $\mathrm{Zn}^{2+}$-binding sites in partially $\mathrm{Zn}^{2+}$ loaded proteins. ${ }^{31}$ We demonstrated how the use of first IAM followed by NEM to label metal-free Cys residues in the presence and absence of $\mathrm{Zn}^{2+}$ is the best choice (Figure 1A).

For this purpose, native ESI-MS and MALDI-MS analysis for metal-free IAM-labeled samples showed modifications ranging from 17 to 20, where the latter was the maximum (Figure 4A,B). Parallel nESI-MS analysis annotated peaks

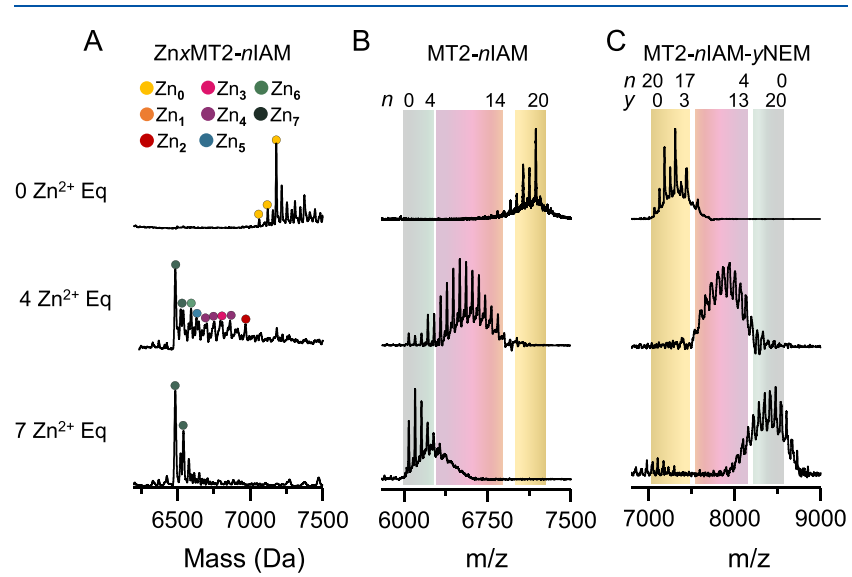

Figure 4. Native ESI-MS (A) and MALDI-MS analysis (B) of apoMT2 with 0,4 , and 7 equiv of $\mathrm{Zn}^{2+}$ to which IAM had been added to a concentration of $1 \mathrm{mM}$ and incubated in darkness for $15 \mathrm{~min}$ at $25{ }^{\circ} \mathrm{C}$. After removal of excess IAM and metal ions, NEM was added to a concentration of $3 \mathrm{mM}$ and incubated for $30 \mathrm{~min}$ at $25^{\circ} \mathrm{C}(\mathrm{C})$. ESI-MS is shown as a deconvolved zero-charge mass spectrum. The $x$, $n$, and $y$ stand for the $\mathrm{Zn}^{2+}$ stoichiometry found for gas-phase ions, the number of IAM modifications, and the number of NEM modifications, respectively. The green, pink, and yellow backgrounds in parts $\mathrm{B}$ and $\mathrm{C}$ refer to the isolated modification profile for 7.4 and 0 $\mathrm{Zn}^{2+}$ equiv added to apoMT2, respectively.

corresponding to $\left[\mathrm{Zn}_{0} \mathrm{IAM}_{18-20} \mathrm{MT} 2\right]^{4+}$, with the fully modified species being the most abundant [Figure 4A and Table S1 (SI)]. After removing the excess IAM, NEM-labeled apoMT2 analyzed by MALDI-MS showed a peak previously fully modified by IAM $(7183.3 \mathrm{~m} / \mathrm{z})$ but also double-labeled peaks with both IAM and NEM (Figure 4C). The distribution of modifications was centered at $7319 \mathrm{~m} / z$, which corresponds to the $\mathrm{IAM}_{18} \mathrm{NEM}_{2} \mathrm{MT} 2$ species with a visible $7308 \mathrm{~m} / z$ peak that comes from overalkylation of $\mathrm{IAM}_{20} \mathrm{NEM}_{1} \mathrm{MT} 2$. With the conditions applied, we only observed one non-cysteine residue reacting with NEM. Double-labeled peaks extended up to forming IAM $_{17} \mathrm{NEM}_{3} \mathrm{MT} 2$ species $(7388 \mathrm{~m} / z)$.

Addition of 4 equiv of $\mathrm{Zn}^{2+}$ to apoMT2 resulted in a wide IAM modification profile ranging from 0 to $14 \mathrm{M}$ with a maximum centered at 8-9 $\mathrm{M}$, which suggests eight or nine noncoordinating Cys residues possibly from the $\beta$-domain (Figure 4B). Comparing both the maximum for apoMT2 (20 $\mathrm{M})$ and the results after addition of 4 equiv of $\mathrm{Zn}^{2+}(8-9 \mathrm{M})$ reveals a difference of $\sim 11-12$ modifications (Figure $4 \mathrm{~B}$ ). This might correspond with the number of Cys residues in the $\alpha$ domain. The nESI-MS analysis confirmed the presence of $\left[\mathrm{Zn}_{4} \mathrm{IAM}_{6-10} \mathrm{MT} 2\right]^{4+}$ ions, but also other $\mathrm{Zn}^{2+}$-to-protein stoichiometries are visible [Figure $4 \mathrm{~A}$ and Table S2 (SI)]. We hypothesized the existence of several conformers, where 4 $\mathrm{Zn}^{2+}$ were located in the $\alpha$-domain or there are redistributed between both $\beta$ - and $\alpha$-domains.

To assess the Cys residues coordinating $\mathrm{Zn}^{2+}$, IAM-labeled $\mathrm{Zn}_{4} \mathrm{MT} 2$ protein samples were DTT-treated with a reduced $\mathrm{pH}$ accompanied by $\mathrm{Zn}^{2+}$ removal and further purification using $\mathrm{C} 18$ resin (Figure 1). As concluded before, NEM might be not able to displace all of the metal ions in proteins that binds $\mathrm{Zn}^{2+}$ with high affinity. To elaborate a general method for proteins that binds $\mathrm{Zn}^{2+}$ with low but also with high affinity, we introduced an acidification step for metal ion removal. Moreover, the acidification and metal ion removal promote destabilization of the natively folded structure, facilitating the access of NEM to all of the Cys residues. ${ }^{24}$ NEM is a suitable reagent for this purpose, since it exhibits fast kinetics even at low $\mathrm{pH}^{26,27}$ The $\mathrm{Zn}^{2+}$ purified protein was then incubated with an excess of NEM. The former population of singly IAM-labeled peaks now appeared doubly labeled with both IAM and NEM moieties (Figure 4C). For instance, the peak centered at 9 IAM now incorporated 11 NEM molecules in the metal-coordinating Cys residues, forming the $\mathrm{IAM}_{9} \mathrm{NEM}_{11}$ MT2 species $(7936 \mathrm{~m} / z)$, which suggests that before to $\mathrm{Zn}^{2+}$ removal, the $\alpha$-domain was fully occupied with $4 \mathrm{Zn}^{2+}$. As in the previous step, where the protein was singly labeled with IAM, multiple products are observed.

Inferring the localization of $\mathrm{Zn}^{2+}$ binding among the Cys residues was achieved with a bottom-up approach. In order to demonstrate the approach presented, we worked with purified proteins or complexes, taking advantage of the speed, sensitivity, and mass accuracy in the analysis provided by the MALDI ion source coupled to the TOF detector. However, one needs to consider other analytical platforms in the case of more complex samples. First, we collected peptide mass fingerprints (PMF) from tryptic fragments measured by MALDI-MS [Figure 1B and Figure S8 (SI)]. A detailed analysis showed an emerging fully modified tryptic fragment, $\mathrm{NEM}_{3}[44-51]$, from the $\mathrm{Zn}_{4} \mathrm{MT}$ sample (Figure S9, SI). This fragment was not previously found in the apoMT2 sample, suggesting that all three Cys residues had bound $\mathrm{Zn}^{2+}$. Congruently, $\mathrm{IAM}_{3}[44-51]$ is no longer visible (Figure S10, SI). Moreover, we observed the appearance of fragment $\mathrm{IAM}_{1} \mathrm{NEM}_{4}$ [31-43] sequenced with IAM-labeled Cys41 accompanied by disappearance of $\mathrm{IAM}_{4}[32-43]$ (Figures S11 and S12, SI). Fragment $\mathrm{NEM}_{3}[52-61]$ from the Cterminal region was also detected, suggesting that it had bound $\mathrm{Zn}^{2+}$. On the other hand, tryptic peptides $\operatorname{NEM}_{1}[21-30]$ and $\mathrm{NEM}_{2}[26-31]$, corresponding to the $\mathrm{N}$-terminal $\beta$-domain, emerged for $\mathrm{Zn}_{4} \mathrm{MT}$. De novo sequencing localized NEMlabeled Cys 21 for the former tryptic peptide and NEM-labeled Cys26 and Cys29 for the latter one (Figures S13 and S14, SI). This was confirmed by observing how fragment $\mathrm{IAM}_{2}[23-31]$ with IAM-labeled Cys26 and Cys29 disappeared (Figure S15, SI). Altogether, the evidence suggests no exclusive selectivity for the first four $\mathrm{Zn}^{2+}$ toward the $\alpha$-domain but partial 
redistribution within the $\beta$-domain region. This is opposite to its $\mathrm{Cd}^{2+}$ counterpart that demonstrated formation of a stable $\mathrm{Cd}_{4} \mathrm{MT}$ intermediate. ${ }^{28}$ In our previous research, we demonstrated an initial sequential $\mathrm{Zn}^{2+}$ binding mechanism for the $\alpha$-domain forming independent $\mathrm{ZnS}_{4}$ sites and $\mathrm{Zn}_{3-4} \mathrm{~S}_{9-10}$ clusters. ${ }^{31}$ Here, by using the presented methodology, our results support the hypothesis of multiple conformations being simultaneously present, where both populations have the full $\alpha$-domain saturated, forming $\mathrm{Zn}^{2+}$ clusters $\left(\alpha-\mathrm{Zn}_{4} \mathrm{MT}\right)$, and with redistributed $\mathrm{Zn}^{2+}$ among the $\alpha$ and $\beta$-domains $\left(\mathrm{Zn}_{3} \alpha \mathrm{Zn}_{1} \beta \mathrm{MT}\right)$ coexisting in solution. Thus, it might be feasible to consider the equilibrium $\alpha \mathrm{Zn}_{4} \mathrm{MT} \rightleftharpoons$ $\mathrm{Zn}_{3} \alpha \mathrm{Zn}_{1} \beta \mathrm{MT}$, which indicates a similar $\mathrm{Zn}^{2+}$ stability between the strongest $\beta$-site and the weakest $\alpha$-site. In a previous $\mathrm{pH}$ titration report, the authors reported a similar conclusion, which supports this idea. ${ }^{72,73}$ A second, alternative option is that there are multiple populations, including $\mathrm{Zn}_{4} \mathrm{MT} 2$ and $\mathrm{Zn}_{5} \mathrm{MT} 2$, coexisting simultaneously. This solution is further supported by native ESI-MS, where we observed multiple metal-loaded species coexisting. The third option includes both solutions, $\mathrm{Zn}_{4} \mathrm{MT}$ with multiple conformations, where $\mathrm{Zn}^{2+}$ ions are redistributed between both domains, and coexisting $\mathrm{Zn}_{4-5} \mathrm{MT}$. Recently, a paper reported collisioninduced unfolding experiments followed through ion mobilityMS for $\mathrm{Zn}_{4} \mathrm{MT} 2$. $^{74}$ The authors reported four separate conformers with regard to collision cross section (CCS) profiles that required a different collision activation for unfolding. The $\beta$-domain is not fully extended but rather folded for $\mathrm{Cd}_{4} \mathrm{MT} 2$, as opposed to $\mathrm{Zn}_{4} \mathrm{MT} 2$, which showed a CCS of around 1000, which corresponds to the $\beta$-domain being fully extended. This may support the idea of an equilibrium, $\alpha \mathrm{Zn}_{4} \mathrm{MT} \rightleftharpoons \mathrm{Zn}_{3} \alpha \mathrm{Zn}_{1} \beta \mathrm{MT}$, that is shifted toward the formation of $\alpha \mathrm{Zn}_{4} \mathrm{MT}$ upon protein destabilization. In agreement, Stillman's group reported that at physiological $\mathrm{pH}$ the four $\mathrm{Zn}^{2+}$ are bound between both domains. ${ }^{75}$ The authors suggested that the terminal Cys5 and Cys7 are involved in $\mathrm{Zn}^{2+}$ coordination. However, this idea has been supported by neither Russell's group nor here. ${ }^{74,75}$ Russell's group concluded that the region from Asn 18 to Cys 38 participates in the coordination of the first four $\mathrm{Zn}^{2+}$ ions, but the terminal Cys5 or Cys7 are at most weakly interacting. Here, with the experimental conditions employed, we suggest that the region 21-30 participates in $\mathrm{Zn}^{2+}$ binding. Despite the above differences, our results agreed and suggested that there exists a $\mathrm{Zn}^{2+}$ redistribution between both $\alpha$ - and $\beta$-domains. ${ }^{74,75}$

Subsequently, addition of 5 equiv of $\mathrm{Zn}^{2+}$ to apoMT2 shifted the distribution of IAM modifications, now centered at 6-7 with a maximum of 10 IAM, clearly right skewed, clumping up populations with few or no IAM modifications (Figure S16A, SI). The complementary, double-labeling distribution obtained was centered, forming the $\mathrm{IAM}_{7} \mathrm{NEM}_{13} \mathrm{MT} 2$ species (8067.5 $\mathrm{m} / z$ ) (Figure S16C, SI). Interestingly, this stoichiometry does not resemble that for coordination of a single $\mathrm{ZnCys}_{4}$ site binding or a completely saturated $\alpha$-cluster $\left(\mathrm{Zn}_{4} \mathrm{~S}_{11}\right)$ but rather suggests a structure with redistributed $\mathrm{Zn}^{2+}$ ions between domains. ${ }^{31}$ Moreover, a mixture of gas-phase ions with $\left[\mathrm{Zn}_{7-3} \mathrm{IAM}_{x} \mathrm{MT} 2\right]^{5+}$ stoichiometry was annotated by $\mathrm{nESI}$, which confirms the products $\mathrm{IAM}_{11} \mathrm{NEM}_{9} \mathrm{MT} 2(7817 \mathrm{~m} / z)$ and $\mathrm{IAM}_{3} \mathrm{NEM}_{17} \mathrm{MT} 2(8339 \mathrm{~m} / z)$ found in MALDI-MS (Figure S16B and Table S3, SI). The former one correlated with $\mathrm{Zn}_{3} \mathrm{~S}_{9}$ stoichiometry and the latter with $\mathrm{Zn}_{6} \mathrm{~S}_{17}$ $\left[\mathrm{Zn}_{4}(\mathrm{Cys})_{11} \alpha\right.$-domain and $\mathrm{Zn}_{2}(\mathrm{Cys})_{6}$ in $\beta$-domain]. Fragments analyzed from PMF traced increased tryptic $\mathrm{NEM}_{1}[26-$
31] with respect to $\mathrm{Zn}_{4} \mathrm{MT}$, which after thorough $\mathrm{MS} / \mathrm{MS}$ sequenced the NEM molecule attached to Cys29 [Figure 1B and Figure S17 (SI)]. The region 1-20 appeared with two IAM modifications for Cys5 and Cys19, so the three remaining Cys residues might be involved in coordination of the fifth $\mathrm{Zn}^{2+}$ (Figure S18, SI). Additionally, tryptic $\mathrm{NEM}_{5}$ [44-61], $\mathrm{NEM}_{4}[31-43]$, and $\mathrm{NEM}_{5}[31-43]$ were detected and sequenced (Figures S19 and S20, SI). These results provide interesting clues concerning the binding of the fifth $\mathrm{Zn}^{2+}$. As the protein is being $\mathrm{Zn}^{2+}$ saturated, the $\alpha$-domain folds to an $\alpha$ $\mathrm{Zn}_{4} \mathrm{~S}_{11}$ cluster and starts to fill the $\beta$-domain. The question arises whether a $\mathrm{Zn}^{2+}$ redistribution between domains occurs, to end up with a coordinated native-like $\alpha$-cluster and a single $\mathrm{ZnS}_{4}$ site in the $\beta$-domain. It is noteworthy how the $\mathrm{ZnS}_{4}$ coordination sphere pinpointed for the single $\beta$-site does not resemble any position from the rabbit X-ray structure but perfectly matches our previous report. ${ }^{31}$ In that study, we indicated that the fifth $\mathrm{Zn}^{2+}$ probably causes conformational changes for the 1-20 and 26-31 sequence regions (Figure 1B). We might confirm that, under the conditions employed, Cys7, Cys13, Cys15, and Cys29 coordinate the fifth $\mathrm{Zn}^{2+}$ (Figure 1B). Notwithstanding, other $\mathrm{Zn}_{5} \mathrm{MT} 2$ populations are simultaneously present, as observed by IM-MS experiments, but likely with lower probability than the one described. ${ }^{49}$

A total of 6 equiv of $\mathrm{Zn}^{2+}$ added to apoMT2 caused an abrupt change of the IAM modification profile, with none to four modifications giving 1 IAM as the most intense peak (Figure S16D). Gas-phase ions detected by the nESI-MS spectrum showed the product ions $\left[\mathrm{Zn}_{7} \mathrm{IAM}_{0-1} \mathrm{MT} 2\right]^{5+}$, $\left[\mathrm{Zn}_{6} \mathrm{IAM}_{3} \mathrm{MT} 2\right]^{5+}$, and $\left[\mathrm{Zn}_{5} \mathrm{IAM}_{3-4} \mathrm{MT} 2\right]^{5+}$ (Figure S16E and Table S4, SI). Likewise, double-labeled proteins showed that various species formed, ranging from $\mathrm{IAM}_{4} \mathrm{NEM}_{16} \mathrm{MT}$ to $\mathrm{IAM}_{0} \mathrm{NEM}_{20} \mathrm{MT}$, the latter corresponding to $\mathrm{Zn}_{7} \mathrm{MT} 2$ (Figure S16F, SI). Precisely, we found a tryptic fragment $\mathrm{NEM}_{2}[23-$ 31] with NEM-labeled Cys24 and Cys29 (Figure S21). These two Cys residues were not previously found to be coordinating and their participation in $\mathrm{Zn}^{2+}$ coordination appears after addition of the 6 equiv of $\mathrm{Zn}^{2+}$. Such results match perfectly with our previous research, validating the approach presented herein. ${ }^{31}$ Addition of the last $\mathrm{Zn}^{2+}$ equivalent did not cause an observable major change for the MALDI modification profile, with the most intensive modification corresponding to one Cys residue (Figure 4B). The nESI-MS results distinguished gasphase ions $\left[\mathrm{Zn}_{7} \mathrm{IAM}_{0} \mathrm{MT} 2\right]^{5+}$ and $\left[\mathrm{Zn}_{7} \mathrm{IAM}_{1} \mathrm{MT} 2\right]^{5+}[$ Figure $4 \mathrm{~A}$ and Table S5 (SI)]. So, after removal of $\mathrm{Zn}^{2+}$, NEM labeled those Cys residues, matching with the stoichiometry obtained from MALDI-MS (Figure 4C). Interestingly, the bottom-up MS results identified the tryptic fragment $\mathrm{NEM}_{1}[21-30]$ with NEM-labeled Cys 21 as still existing in the spectra, confirming the gating role of Cys 21 for the seventh $\mathrm{Zn}^{2+}$ previously reported [Figure $1 \mathrm{~B}$ and Figure S22 (SI)]. ${ }^{31}$

\section{CONCLUSION}

Cysteine is the most nucleophilic amino acid residue of all building proteins; a target for reactive oxygen, nitrogen, and sulfur species and numerous chemical reactions, including post-translational ones; and critical for binding essential and toxic metal ions. To identify the chemical or redox state of Cys residues in proteins, analytical methods are based on reactions with thiol-specific probes. Among them, IAM and NEM are commonly used following an $S_{\mathrm{N}} 2$ reaction and nucleophilic addition, respectively. Differential labeling coupled to mass spectrometry is used for mapping metal-binding sites. In 
principle, a single labeling approach should be sufficient to pinpoint $\mathrm{Zn}_{x}(\mathrm{Cys})_{y}$ protein sites, on which the $\mathrm{Zn}^{2+}$-bound thiolate would exhibit lower reactivity toward electrophiles. However, this is not the case for low- or moderate-affinity $\mathrm{Zn}^{2+}$-binding sites, where unwanted metal ion dissociation during protein modification might occur. Moreover, a similar reactivity for a $\mathrm{Zn}^{2+}$-bound and free Cys residue with low $\mathrm{p} K_{\mathrm{a}}$ might occur, hampering their nucleophilic differentiation. Herein, we developed a dual-labeling methodology to overcome these obstacles. Our findings suggested proceeding with an $S_{N} 2$ reaction with IAM or a similar reagent, but not with a nucleophilic addition provided by maleimides, to label free Cys residues and avoid $\mathrm{Zn}^{2+}$ dissociation. The small size and hydrophilic character permits the labeling of free Cys residues, regardless if they are buried or not. Once the free Cys residues are labeled, metal-bound Cys might easily be labeled by a second nucleophile after extraction of the metal ion by acidification and followed by reverse-phase C18 separation. A priori, $\mathrm{Zn}^{2+}$ removal can be approached by increasing the alkylator concentration or reaction time. However, this approach does not work for high-stability metal-protein sites, and substantial overalkylation may occur. Thus, the acidification step ensures metal ion removal independent of how strongly it is bound. Not only the metal-to-protein affinity but also the thiol accessibility may limit the labeling reaction. The acidification step greatly facilitates the access of the second alkylator to all of the Cys residues, even if they were buried in the protein structure. Although any reagent different than IAM would in principle work for the second labeling reaction, NEM reacts faster than iodoacetamide derivatives with thiols/thiolates, even at low $\mathrm{pH}$.

This research demonstrated how the combination of inexpensive standard labeling reagents and mass spectrometry can directly map metal-binding sites in Cys-rich proteins. Lastly, the methodology presented is very encouraging and illustrates its future use to study other metal-binding Cys proteins.

\section{ASSOCIATED CONTENT}

\section{SI Supporting Information}

The Supporting Information is available free of charge at https://pubs.acs.org/doi/10.1021/acs.analchem.0c01604.

Detailed materials and protocol for expression and purification of MTs; MALDI-MS spectra of $\mathrm{Cd}_{7} \mathrm{MT} 2$ and $\mathrm{Zn}_{7} \mathrm{MT} 2$, to which $15-3600$ equiv of NEM or IAM had been added, after $60 \mathrm{~min}$ of incubation; UV-vis spectra of the metal displacement reactions after $60 \mathrm{~min}$ incubation with $0-3600$ equiv of IAM and NEM with $\mathrm{Cd}_{7} \mathrm{MT} 2$ and $\mathrm{Zn}_{7} \mathrm{MT} 2$; ESI-MS spectra of $\mathrm{Cd}_{7} \mathrm{MT} 2$ and $\mathrm{Zn}_{7} \mathrm{MT} 2$ incubated with increasing equivalents of IAM and NEM for $60 \mathrm{~min}$; ESI-MS spectra after $60 \mathrm{~min}$ of incubation with 750 or 1400 equiv of IAM and NEM with $\mathrm{Cd}_{7} \mathrm{MT} 2$ and $\mathrm{Zn}_{7} \mathrm{MT} 2$; number of Cys modified determined by MALDI-MS as a function of alkylator/ MT ratio after $60 \mathrm{~min}$ incubation; peptide mass fingerprint for IAM and NEM labeling for $\mathrm{Zn}_{4} \mathrm{MT} 2$, $\mathrm{Zn}_{5} \mathrm{MT} 2, \mathrm{Zn}_{6} \mathrm{MT} 2$, and $\mathrm{Zn}_{7} \mathrm{MT} 2$ samples analyzed by MALDI-MS; MALDI-MS/MS analysis for the tryptic fragment of $\mathrm{Zn}_{0} \mathrm{MT} 2, \mathrm{Zn}_{4} \mathrm{MT} 2, \mathrm{Zn}_{5} \mathrm{MT} 2, \mathrm{Zn}_{6} \mathrm{MT} 2$, and $\mathrm{Zn}_{7} \mathrm{MT} 2$ samples; gas-phase ions annotated for $\mathrm{Zn}_{4} \mathrm{MT} 2, \mathrm{Zn}_{5} \mathrm{MT} 2, \mathrm{Zn}_{6} \mathrm{MT} 2$, and $\mathrm{Zn}_{7} \mathrm{MT} 2$ samples labeled with IAM (Figures S1-S22 and Tables S1-S5) (PDF)

\section{AUTHOR INFORMATION}

\section{Corresponding Author}

Artur Krężel - Department of Chemical Biology, Faculty of Biotechnology, University of Wroctaw, 50-383 Wroctaw, Poland; 10 orcid.org/0000-0001-9252-5784; Phone: +48 71 375 2765; Email: artur.krezel@uwr.edu.pl

\section{Authors}

Manuel David Peris-Díaz - Department of Chemical Biology, Faculty of Biotechnology, University of Wroctaw, 50-383 Wroctaw, Poland; 10 orcid.org/0000-0002-5025-9614

Roman Guran - Department of Chemistry and Biochemistry, Mendel University in Brno, 61300 Brno, Czech Republic; Central European Institute of Technology, Brno University of Technology, 61200 Brno, Czech Republic; (1) orcid.org/00000002-2912-714X

Ondrej Zitka - Department of Chemistry and Biochemistry, Mendel University in Brno, 61300 Brno, Czech Republic; Central European Institute of Technology, Brno University of Technology, 61200 Brno, Czech Republic

Vojtech Adam - Department of Chemistry and Biochemistry, Mendel University in Brno, 61300 Brno, Czech Republic; Central European Institute of Technology, Brno University of Technology, 61200 Brno, Czech Republic; (ㅇoㅇid.org/00000002-8527-286X

Complete contact information is available at:

https://pubs.acs.org/10.1021/acs.analchem.0c01604

\section{Notes}

The authors declare no competing financial interest.

\section{ACKNOWLEDGMENTS}

This research was supported by the National Science Centre of Poland (NCN) under the Opus grant no. 2018/31/B/NZ1/ 00567 (to A.K.). M.D.P.-D. thanks the Erasmus+ program and the Polish National Agency for Academic Exchange under the PROM program (grant no. PPI/PRO/2018/1/00007/U/00). V.A. would like to thank to the European Research Council (ERC) for financial support from the European Union's Horizon 2020 Research and Innovation Programme (grant agreement no. 759585).

\section{REFERENCES}

(1) Andreini, C.; Banci, L.; Bertini, I.; Rosato, A. J. Proteome Res. 2006, 5, 196-201.

(2) Andreini, C.; Banci, L.; Bertini, I.; Rosato, A. J. Proteome Res. 2006, 5, 3173-3178.

(3) Kochańczyk, T.; Drozd, A.; Krężel, A. Metallomics. 2015, 7, 244257.

(4) Maret, W.; Li, Y. Chem. Rev. 2009, 109, 4682-4707.

(5) Maret, W. BioMetals 2011, 24, 411-418.

(6) Ye, B.; Maret, W.; Vallee, B. L. Proc. Natl. Acad. Sci. U. S. A. 2001, 98, 2317-2322.

(7) Apostolova, M. D.; Ivanova, I. A.; Cherian, M. G. Toxicol. Appl. Pharmacol. 1999, 159, 175-184.

(8) Krężel, A.; Maret, W. Int. J. Mol. Sci. 2017, 18, 1237.

(9) Blindauer, C. A.; Leszczyszyn, O. I. Nat. Prod. Rep. 2010, 27, $720-741$.

(10) Capdevila, M.; Atrian, S. JBIC, J. Biol. Inorg. Chem. 2011, 16, 977-989. 
(11) Banci, L.; Bertini, I. In Metallomics and the Cell; Banci, L., Ed.; Springer, 2013; pp 1-13.

(12) Maret, W. Zinc and Zinc Ions in Biological Systems. In Encyclopedia of Metalloproteins; Kretsinger, R. H., Uversky, V. N., Permyakov, E. A., Eds.; Springer-Verlag: New York, 2013; p 87.

(13) Paulsen, C. E.; Carroll, K. S. Chem. Rev. 2013, 113, 4633-4679.

(14) Chung, H. S.; Wang, S.-B.; Venkatraman, V.; Murray, C. I.; Van

Eyk, J. E. Circ. Res. 2013, 112, 382-392.

(15) Beck-Sickinger, A. G.; Mörl, K. Posttranslational Modification of Proteins: Expanding Nature's Inventory; Roberts \& Co. Publishers: Englewood, CO, 2005; pp 121-123.

(16) Gunnoo, S. B.; Madder, A. ChemBioChem 2016, 17, 529-553.

(17) Maret, W. Free Radical Biol. Med. 2019, 134, 311-326.

(18) Krężel, A.; Maret, W. JBIC, J. Biol. Inorg. Chem. 2006, 11, 1049-1062.

(19) Krężel, A.; Hao, Q.; Maret, W. Arch. Biochem. Biophys. 2007, 463, 188-200.

(20) Hartwig, A. Free Radical Biol. Med. 2013, 55, 63-72.

(21) Alcock, L. J.; Perkins, M. V.; Chalker, J. M. Chem. Soc. Rev. 2018, 47, 231-268.

(22) Chalker, J. M.; Bernardes, G. J. L.; Lin, Y. A.; Davis, B. G. Chem. - Asian J. 2009, 4, 630-640.

(23) Awoonor-Williams, E.; Rowley, C. N. J. Chem. Theory Comput. 2016, 12, 4662-4673.

(24) Marino, S. M.; Gladyshev, V. N. J. Biol. Chem. 2012, 287, $4419-4425$

(25) Wojdyla, K.; Rogowska-Wrzesinska, A. Redox Biol. 2015, 6, 240-252.

(26) Paulech, J.; Solis, N.; Cordwell, S. J. Biochim. Biophys. Acta, Proteins Proteomics 2013, 1834, 372-379.

(27) Hill, B. G.; Reily, C.; Oh, J. Y.; Johnson, M. S.; Landar, A. Free Radical Biol. Med. 2009, 47, 675-683.

(28) Chen, S. H.; Russell, D. H. Biochemistry 2015, 54 (39), 60216028.

(29) Bernhard, W. R.; Vašák, M.; Kägi, J. H. R. Biochemistry 1986, $25,1975-1980$

(30) Shaw, C. F.; He, L.; Muñoz, A.; Savas, M. M.; Chi, S.; Fink, C. L.; Gan, T.; Petering, D. H. JBIC, J. Biol. Inorg. Chem. 1997, 2, 65-73.

(31) Drozd, A.; Wojewska, D.; Peris-Díaz, M. D.; Jakimowicz, P.; Kręzel, A. Metallomics 2018, 10, 595-613.

(32) Seiwert, B.; Hayen, H.; Karst, U. J. Am. Soc. Mass Spectrom. 2008, 19, 1-7.

(33) Schilling, B.; Yoo, C. B.; Collins, C. J.; Gibson, B. W. Int. J. Mass Spectrom. 2004, 236, 117-127.

(34) McDonagh, B.; Sakellariou, G. K.; Smith, N. T.; Brownridge, P.; Jackson, M. J. J. Proteome Res. 2014, 13, 5008-5021.

(35) Held, J. M.; Danielson, S. R.; Behring, J. B.; Atsriku, C.; Britton, D. J.; Puckett, R. L.; Schilling, B.; Campisi, J.; Benz, C. C.; Gibson, B. W. Mol. Cell. Proteomics 2010, 9, 1400-1410.

(36) Weerapana, E.; Wang, C.; Simon, G. M.; Richter, F.; Khare, S.; Dillon, M. B. D.; Bachovchin, D. A.; Mowen, K.; Baker, D.; Cravatt, B. F. Nature 2010, 468, 790-797.

(37) Chen, S.-H.; Russell, W. K.; Russell, D. H. Anal. Chem. 2013, $85,3229-3237$.

(38) Hong, S.-H.; Hao, Q.; Maret, W. Protein Eng., Des. Sel. 2005, 18, 255-263.

(39) Potier, N.; Rogniaux, H.; Chevreux, G.; Van Dorsselaer, A. Methods Enzymol. 2005, 402, 361-389.

(40) Irvine, G. W.; Santolini, M.; Stillman, M. J. Protein Sci. 2017, 26, 960-971.

(41) Chen, S.-H.; Chen, L.; Russell, D. H. J. Am. Chem. Soc. 2014, 136, 9499-9508.

(42) Pace, N. J.; Weerapana, E. ACS Chem. Biol. 2014, 9, 258-265.

(43) Puljung, M. C.; Zagotta, W. N. Biophys. J. 2011, 100, 25132521.

(44) Lee, Y. M.; Lim, C. J. Am. Chem. Soc. 2011, 133, 8691-8703.

(45) Scotcher, J.; Clarke, D. J.; Weidt, S. K.; Mackay, C. L.; Hupp, T. R.; Sadler, P. J.; Langridge-Smith, P. R. R. J. Am. Soc. Mass Spectrom. 2011, 22, 888-897.
(46) Kopera, E.; Schwerdtle, T.; Hartwig, A.; Bal, W. Chem. Res. Toxicol. 2004, 17, 1452-1458.

(47) Krężel, A.; Maret, W. J. Am. Chem. Soc. 2007, 129, 1091110921.

(48) Britto, P. J.; Knipling, L.; Wolff, J. J. Biol. Chem. 2002, 277, $29018-29027$.

(49) Chen, S. H.; Chen, L. X.; Russell, D. H. J. Am. Chem. Soc. 2014, 136, 9499-9508.

(50) Poltash, M. L.; McCabe, J. W.; Shirzadeh, M.; Laganowsky, A.; Clowers, B. H.; Russell, D. H. Anal. Chem. 2018, 90, 10472-10478.

(51) Rose, R. J.; Damoc, E.; Denisov, E.; Makarov, A.; Heck, A. J. R. Nat. Methods 2012, 9, 1084-1086.

(52) Kondrat, F. D. L.; Kowald, G. R.; Scarff, C. A.; Scrivens, J. H.; Blindauer, C. A. Chem. Commun. 2013, 49, 813-815.

(53) Martin, E. M.; Kondrat, F. D. L.; Stewart, A. J.; Scrivens, J. H.; Sadler, P. J.; Blindauer, C. A. Sci. Rep. 2018, 8, 8646.

(54) Pagel, K.; Natan, E.; Hall, Z.; Fersht, A. R.; Robinson, C. V. Angew. Chem., Int. Ed. 2013, 52, 361-365.

(55) Jurneczko, E.; Cruickshank, F.; Porrini, M.; Clarke, D. J.; Campuzano, I. D. G.; Morris, M.; Nikolova, P. V.; Barran, P. E. Angew. Chem., Int. Ed. 2013, 52, 4370-4374.

(56) Arlt, C.; Flegler, V.; Ihling, C. H.; Schäfer, M.; Thondorf, I.; Sinz, A. Angew. Chem., Int. Ed. 2017, 56, 275-279.

(57) Perez-Zúñiga, C.; Leiva-Presa, A.; Austin, R. N.; Capdevila, M.; Palacios, O. Metallomics 2019, 11, 349-361.

(58) Yu, X.; Wojciechowski, M.; Fenselau, C. Anal. Chem. 1993, 65, 1355-1359.

(59) Peris-Díaz, M. D.; Richtera, L.; Zitka, O.; Krężel, A.; Adam, V. Bioelectrochemistry 2020, 134, 107501.

(60) Mendoza, V. L.; Vachet, R. W. Mass Spectrom. Rev. 2009, 28, $785-815$.

(61) He, L.; Weisbrod, C. R.; Marshall, A. G. Int. J. Mass Spectrom. 2018, 427, 107-113.

(62) Powlowski, J.; Sahlman, L. J. Biol. Chem. 1999, 274, 3332033326.

(63) Sikorska, M.; Krężel, A.; Otlewski, J. J. Inorg. Biochem. 2012, $115,28-35$.

(64) Kochanczyk, T.; Nowakowski, M.; Wojewska, D.; Kocyla, A.; Ejchart, A.; Kozminski, W.; Krężel, A. Sci. Rep. 2016, 6, 36346.

(65) Kocyła, A.; Pomorski, A.; Krężel, A. J. Inorg. Biochem. 2017, $176,53-65$.

(66) Kocyła, A.; Pomorski, A.; Krężel, A. J. Inorg. Biochem. 2015, $152,82-92$.

(67) Suckau, D.; Resemann, A.; Schuerenberg, M.; Hufnagel, P.; Franzen, J.; Holle, A. Anal. Bioanal. Chem. 2003, 376, 952-965.

(68) Bakhtiari, M.; Konermann, L. J. Phys. Chem. B 2019, 123, $1784-1796$

(69) Konermann, L. J. Am. Soc. Mass Spectrom. 2017, 28, 18271835.

(70) Xia, Z.; Degrandchamp, J. B.; Williams, E. R. Analyst 2019, 144, $2565-2573$

(71) Susa, A. C.; Xia, Z.; Williams, E. R. Anal. Chem. 2017, 89, $3116-3122$

(72) Vasak, M.; Kagi, J. H. R.; Hill, H. A. O. Biochemistry 1981, 20, $2852-2856$

(73) Hong, S. H.; Toyama, M.; Maret, W.; Murooka, Y. Protein Expression Purif. 2001, 21, 243-250.

(74) Dong, S.; Wagner, N. D.; Russell, D. H. Anal. Chem. 2018, 90, 11856-11862.

(75) Irvine, G. W.; Pinter, T. B. J.; Stillman, M. J. Metallomics 2016, $8,71-81$ 